vides one of the vital bridges that must be undergirded and expanded if we are to develop our full potential as individuals, as a profession, and as a nation.

Second, he is an individual of great character. Everyone thinks the world of Lucius Barker. His wit, grace, and friendliness are surpassed only by his willingness to help others, his integrity, and his unpretentiousness. Barker has, of course, achieved success by any standard. He must be prodded, however, to acknowledge the hurdles he has overcome. $\mathrm{He}$ is of a generation and milieu that is not comfortable focusing on one's accomplishments and difficulties. Indeed, until only recently, stories such as the one about the voting registrar were seldom told. He reluctantly relates them now only because he understands their significance to modern-day versions of different but nonetheless notable barriers.

Finally, rarely does one possess, as Barker does, the qualities and drive needed to achieve distinction in each of the important areas of the academy: teaching, research, and service. As such, Barker's career sets an enviable standard for all who are now or would be members of the profession and the academy.

\section{Chicago Annual Meeting}

The 88th Annual Meeting of the American Political Science Association set a new attendance record for meetings held outside of Washington, D.C., and was the second largest meeting ever held, drawing 4,998 registrants. Featured at the meeting were the Harold D. Lasswell Symposium on "America in a New World" featuring Winston Lord, Joseph S. Nye, Jr., Norman J. Ornstein, and Condoleezza Rice, and James Q. Wilson's Presidential Address on "The Moral Sense." An APSA/IPSA symposium on the Human Dimension of Global Envi-

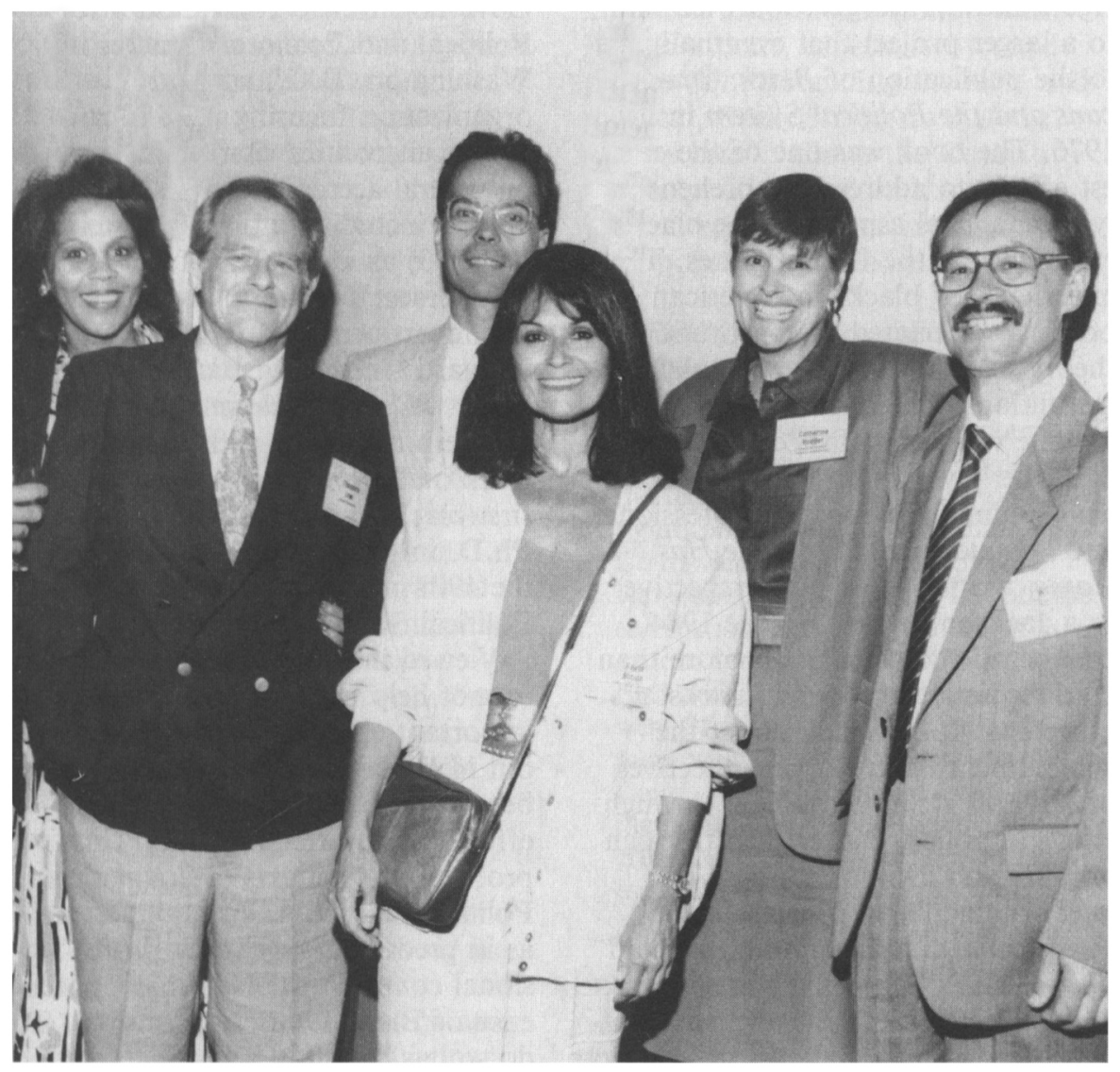

From the left: Paula McClain, Theodore J. Lowi, Gregory Caldeira, Gayle Binion, Catherine Rudder, and William Smirnov at the president-elect reception, APSA Annual Meeting. ronmental Change was held simultaneously with the meeting.

The meeting was organized by Thomas E. Mann of the Brookings Institution, along with 41 members of the Program Committee. The Program Committee was composed of program organizers drawn from individuals nominated by each of the 28 organized sections within APSA, as well as program section chairs appointed by Mann. The meeting included more panel sessions than any previous meeting - 466 panels organized by the Program Committee and 79 by related groups for a total of 545 panels. Last year's meeting offered 509. The Palmer House Hotel offered up its usual charms for the meeting, as well as tight corners and a split-level exhibition hall.

Panel attendance averaged 28 people per panel. This is below the 31 person average for last year's meeting, but given the increased number of panels actually reflects an equivalent level of overall panel attendance. Sections of the meeting showing the strongest panel attendance overall were panels on the foundations of political theory, international collaboration, normative theory, international political economy, the presidency, and history and politics.

The largest individual panel attendance was for a roundtable on the philosophy of Richard Rorty, chaired by Richard E. Flathman of Johns Hopkins University, and for a paper panel on neorealism, neoliberalism, and the study of collaboration chaired by David Baldwin of Columbia University. Each drew 200 people.

Roundtables on election forecasting and on renewing Congress, chaired by Tom Mann, and on social science perspectives on the Los Angeles riots, chaired by Sidney Tarrow of Cornell University also drew large numbers of people. Along with the panel on neorealism, panels in which papers were presented which drew the largest audience were "Rousseau and the Politics of the Heart" chaired by Ruth W. Grant of Duke University, "The American Foreign Policy After the Cold War" chaired by Joseph Nye of Harvard University, "Do Liberal Democracies Fight Each Other?" chaired by Duncan Snidal of the University of 
Chicago, and "Political Transformations of the Self" chaired by Jane Mansbridge of Northwestern University.

Several panels organized by related groups also drew a large attendance, including a roundtable organized by the Washington Post featuring APSA Council member David Broder and other Post reporters and three panels organized by the Claremont Institute titled "Rights and Modernity" chaired by Ken Masugi of the EEOC, "A Roundtable on Fukuyama's The End of Liberalism and the Last Man," chaired by Edward J. Erler of California State University, San Bernadino, and "A Roundtable on the Ennobling of Democracy: The Challenge of PostModernism" chaired by Daniel Mahoney of Assumption College. On Thursday evening, President Wilson gave his Presidential address, "The Moral Sense," which will be printed in the March issue of the Review, as is customary. His address followed the presentation of APSA awards.

Martha Derthick, University of Virginia, received the John Gaus Award on Friday evening, and offered the Gaus Lecture; her remarks are reprinted in this issue of PS. Senator Daniel Patrick Moynihan gave the Pi Sigma Alpha Guest Lecture, which is now held annually in conjunction with the meeting.

\section{Association Distributes Annual Awards}

Dissertations submitted by Harvard University won two of seven dissertation awards presented at the Awards Ceremony at the Annual Meeting September 3. Nancy Elizabeth Burns, now at the University of Michigan, was presented the William Anderson Award in the field of intergovernmental relations; Beth A. Simmons, currently at Duke University, was the recipient of the Helen Dwight Reid Award in the field of international relations, law and politics. Sidney Verba and Robert Keohane were the respective dissertation chairs.

Other dissertation winners were Felipe Aguero, Ohio State Univer- sity, the Gabriel Almond Award in the field of comparative politics, Peter Lange of Duke University dissertation chair; Yu-Shan Wu, National Taiwan University, the Harold D. Lasswell Award in the field of policy studies, Chalmers Johnson and Lowell Dittmer of the University of California, Berkeley, dissertation chairs; George Douglas Dion, University of Michigan, the E. E.

Schattschneider Award in the field of American government and politics, John Kingdon of the University of Michigan dissertation chair; Peter C. Myers, University of Wisconsin, Eau Claire, the Leo Strauss Award in the field of political philosophy, James L. Wiser of Loyola University of Chicago, dissertation chair; Bartholomew H. Sparrow, University of Texas at Austin, the Leonard D. White Award in the field of public administration, John Padgett of the University of Chicago dissertation chair. The Edward S. Corwin Award in the field of public law was not conferred this year.

Stuart Elaine MacDonald, University of North Carolina at Chapel Hill; Ola Listhaug, University of Trondheim; and George Rabinowitz, University of North Carolina at Chapel Hill, won the Heinz Eulau Award for the best article published in the American Political Science Review during 1990. Edgar Kiser, University of Washington, was the recipient of the Franklin L. Burdette Pi Sigma Alpha Award for the best paper presented at the 1991 Annual Meeting.

Book award winners included Donald L. Horowitz, Duke University, who won the Ralph J. Bunche Award for the best scholarly work published in 1991 which explores the phenomenon of ethnic and cultural pluralism for his $A$ Democratic South Africa? Constitutional Engineering in a Divided Society, published by the University of California Press. D. Roderick Kiewiet, California Institute of Technology, and Mathew D. McCubbins, University of California, San Diego, were presented the Gladys M. Kammerer Award for the best publication in 1991 in the field of U.S. national policy for their book The Logic of Delegation: Congressional Parties and the Appropriations Process, published by the University of Chicago Press. The Victoria Schuck Award for the best book published in 1991 on women and politics was shared by Nancie Caraway of American University, for Segregated Sisterhood: Racism and the Politics of American Feminism, published by the University of Tennessee Press; and Anne Phillips of City of London

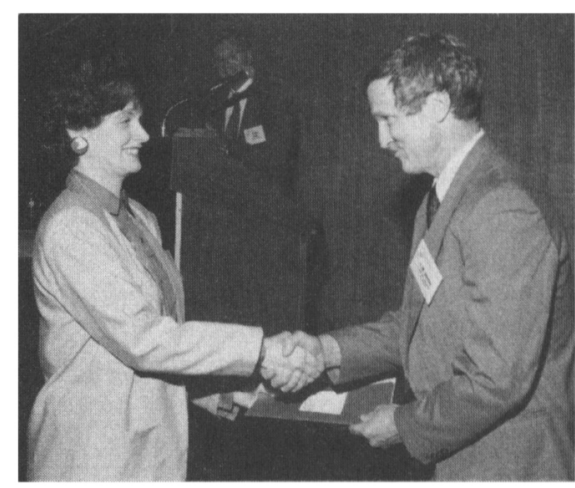

Beth A. Simmons receives the Helen Dwight Reid Award from I. M. Destler.

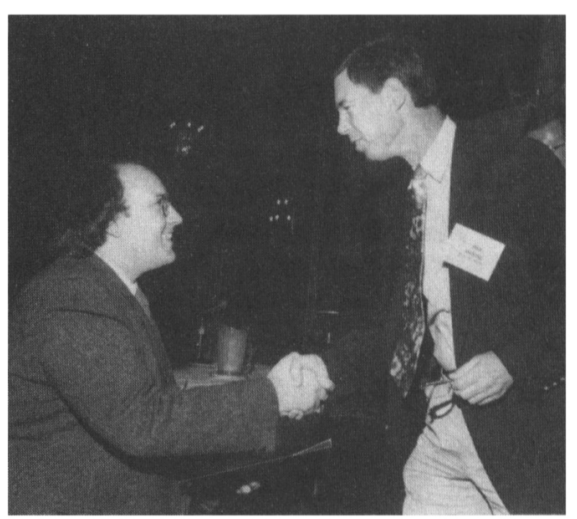

George Douglas Dion receives the E. E. Schattschneider Award from John Jackson.

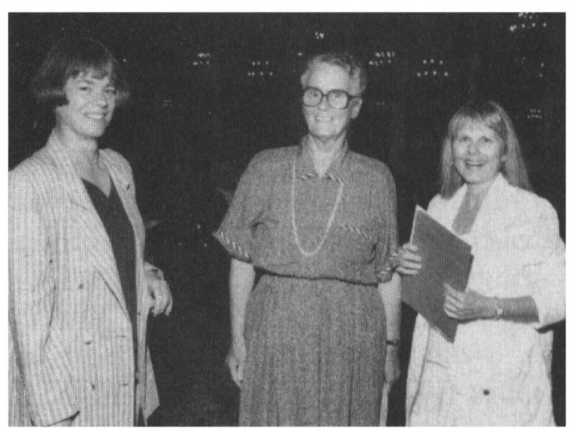

Mary Cornelia Porter (center), chair of the Victoria Schuck Book Award Committee, with award recipients, Anne Phillips (1) and Nancie Caraway (r). 